\title{
Akibat Hukum Penyalahgunaan Wewenang Administrasi Pejabat Pemerintahan yang Menimbulkan Kerugian Keuangan Negara
}

\author{
Henny Juliani \\ Fakultas Hukum, Universitas Diponegoro \\ hennyjuliani@gmail.ac.id
}

\begin{abstract}
In governmental implementation, government officers execute function of regulating, serving, developing, empowering, and protecting in order to create people welfare. In implementation of the functions government officers have authority to make decision and/or action, therefore government officers are forbid abusing their authority. Supervision on authority abuse of government officers is condeucted by APIP. Result of supervision by APIP is comprised of without mistakes, with administrative mistakes, or with administrative mistake which potentially cause state financial loss. Legal consequency of govenrment officers on authority abuse which cause state financial loss due to maladministration become the responsibility of the government officers themselves respectively by returning the same amount of state financial loss due to authority abuse. Based on APIP supervision report, the government officers accused of doing authority abuse, may request to be assessed to find out whether there is authority abuse or not when the government officers decree and/or execute their policies, before it become criminal proceeding. The request is porposed to PTUN based on Regulation og Royal Court Number 4 of 2015.
\end{abstract}

Keywords: Administrative Authority Abuse, State Financial Loss

\begin{abstract}
Abstrak
Dalam penyelenggaraan pemerintahan, pejabat pemerintahan melaksanakan fungsi pengaturan, pelayanan, pembangunan, pemberdayaan, dan perlindungan bagi peningkatan kesejahteraan rakyat. Dalam melaksanakan fungsi tersebut pejabat pemerintahan memperoleh wewenang untuk mengambil keputusan dan/atau tindakan, oleh karena itu maka pejabat pemerintahan dilarang menyalahgunakan wewenang. Pengawasan terhadap larangan penyalahgunaan wewenang tersebut dilakukan oleh APIP. Hasil pengawasan APIP berupa: tidak terdapat kesalahan, terdapat kesalahan administratif, atau terdapat kesalahan administratif yang menimbulkan kerugian keuangan negara. Akibat hukum pejabat pemerintahan terhadap penyalahgunaan wewenang yang menimbulkan kerugian keuangan negara karena adanya kesalahan administratif/maladministratif menjadi tanggung jawab pribadi dengan mengembalikan kerugian keuangan negara yang ditimbulkan sebagai akibat dari perbuatan yang dia lakukan. Berdasarkan hasil pengawasan APIP tersebut, pejabat pemerintahan yang dianggap telah melakukan penyalahgunaan wewenang, dapat mengajukan permohonan penilaian unsur ada tidaknya penyalahgunaan wewenang dalam mengeluarkan keputusan dan/atau tindakan kepada Peradilan Tata Usaha Negara berdasarkan Peraturan Mahkamah Agung Nomor 4 Tahun 2015, sebelum adanya proses pidana.
\end{abstract}

Kata Kunci: Penyalahgunaan Wewenang Administrasi, Kerugian Keuangan Negara 


\section{A. Pendahuluan}

Indonesia menganut konsep negara hukum baru yang lebih dinamis yakni yang dikenal dengan istilah welfare state (negara kesejahteraan) atau negara hukum materiil. Di dalam negara hukum modern welfare state ini tugas pemerintah bukan lagi sebagai penjaga malam dan tidak boleh pasif tetapi harus aktif turut serta dalam kegiatan masyarakat sehingga kesejahteraan bagi semua orang tetap terjamin. Jadi di dalam welfare state pemerintah itu diserahi bestuurzorg yaitu penyelenggaraan kesejahteraan umum. ${ }^{1}$

Asshiddiqie sebagaimana dikutip oleh W Riawan Tjandra menguraikan bahwa dalam konsep negara kesejahteraan ini, negara dituntut untuk memperluas tanggung jawabnya kepada masalah-masalah sosial ekonomi yang dihadapi rakyat banyak. Perkembangan inilah yang memberikan legalisasi bagi 'negara intervensionis' abad ke 20. Walhasil dengan intervensi ini fungsi negara juga meliputi kegiatan-kegiatan yang sebelumnya berada di luar jangkauan fungsi negara, seperti memperluas ketentuan pelayanan sosial kepada individu dan keluarga dalam hal-hal khusus seperti 'social security', kesehatan, kesejahteraan sosial, pendidikan, dan pelatihan serta perumahan. $^{2}$

Soekanto seperti yang dikutip oleh W. Riawan Tjandra menyatakan apabila semula negara hanya dipandang sebagai instrument of power, maka mulai timbul aliran-aliran yang menganggap negara sebagai agency of service, maka timbullah konsep welfare state yang terutama memandang manusia tidak hanya sebagai individu, akan tetapi juga sebagai anggota atau warga dari kolektiva dan bahwa manusia bukanlah semata-mata merupakan alat kepentingan kolektiva akan tetapi juga untuk tujuan diri sendiri. ${ }^{3}$

Alinea IV dan Pasal 33 Undang-Undang Dasar Negara Republik Indonesia Tahun 1945 memberikan tugas dan tanggung jawab kepada Pemerintah untuk mewujudkan kesejahteraan rakyat melalui kewenangan untuk mengelola keuangan negara sehingga

SF Marbun dan Moh. Mahfud MD, Pokok-pokok Hukum Administrasi Negara, (Yogyakarta: Liberty, 1987), halaman 45

2 W Riawan Tjandra, Hukum Administrasi Negara, (Yogyakarta: Penerbit Universitas Atma Jaya, 2008), halaman 9.

Ibid, halaman 11-12 
tugas-tugas negara tersebut dapat segera diwujudkan. Kewenangan negara tersebut diperoleh pemerintah berdasarkan Pasal 23 ayat (1), (2), dan (3) Undang-Undang Dasar Negara Republik Indonesia Tahun 1945 sebagai landasan konstitusional.

Selanjutnya Pasal 23 C UUD NRI Tahun 1945 menyatakan bahwa: "Hal-hal lain mengenai keuangan negara diatur dengan undang-undang." Ketentuan Pasal $23 \mathrm{C}$ tersebut selanjutnya diimplementasikan melalui 3 (tiga) paket undang-undang yaitu Undang-Undang Nomor 17 Tahun 2003 tentang Keuangan Negara, Undang-Undang Nomor 1 Tahun 2004 tentang Perbendaharaan Negara, dan Undang-Undang Nomor 15 Tahun 2004 tentang Pemeriksaan Pengelolaan dan Tanggung Jawab Keuangan Negara. Terminologi keuangan negara menurut Undang-Undang Nomor 17 Tahun 2003 tentang Keuangan Negara dapat dilihat dalam rumusan Pasal 1 angka 1, bahwa yang dimaksud dengan keuangan negara adalah semua hak dan kewajiban negara yang dapat dinilai dengan uang, serta segala sesuatu baik berupa uang maupun berupa barang yang dapat dijadikan milik negara berhubung dengan pelaksanaan hak dan kewajiban tersebut.

Kewenangan untuk mengelola keuangan negara sebagai instrumen dalam mewujudkan kesejahteraan rakyat secara atribusi diberikan kepada Presiden berdasarkan Pasal 6 ayat (1) Undang-Undang Nomor 17 Tahun 2013 tentang Keuangan Negara. Pengelolaan keuangan negara yang dilaksanakan oleh Presiden dan pejabat pemerintahan lainnya dalam penyelenggaraan fungsi pemerintahan yang meliputi fungsi pengaturan, pelayanan, pembangunan, pemberdayaan, dan perlindungan harus didasarkan pada asas legalitas, asas-asas umum pemerintahan yang baik (AUPB) dan good governance yang telah tertuang dalam berbagai peraturan perundang-undangan di Indonesia. Salah satunya adalah Undang-Undang Nomor 30 Tahun 2014 tentang Administrasi Pemerintahan.

Penjelasan Umum Undang-Undang Nomor 30 Tahun 2014 menyatakan bahwa undang-undang ini merupakan transformasi AUPB yang telah dipraktikkan selama berpuluh-puluh tahun dalam penyelenggaraan pemerintahan, dan dikonkretkan ke dalam norma hukum yang mengikat. Undang-undang ini berpijak pada asas-asas yang berkembang dan telah menjadi dasar dalam penyelenggaraan pemerintahan di Indonesia selama ini. Undang-undang ini menjadi dasar hukum dalam 
penyelenggaraan pemerintahan di dalam upaya meningkatkan kepemerintahan yang baik (good governance) dan sebagai upaya untuk mencegah praktik korupsi, kolusi, dan nepotisme. Dengan demikian, undang-undang ini harus mampu menciptakan birokrasi yang semakin baik, transparan, dan efisien.

Salah satu keuntungan dari sistem pemerintah yang menerapkan prinsip-prinsip good governance adalah bahwa pemerintahan tersebut akan terhindar dari perbuatanperbuatan tercela, terutama yang dilakukan oleh pihak insider pemerintahan. Memang, dengan diterapkannya prinsip good governance dengan dukungan dari regulasi yang baik, dapat menyebabkan pemerintah terhindar dari tindakan tercela, seperti mencegah berbagai bentuk over stated terhadap kegiatan atau keuangan negara, ketidakjujuran dalam melakukan kegiatan yang berkenaan dengan masalah keuangan, dan berbagai tindakan tercela lainnya yang berkaitan dengan keuangan negara. ${ }^{4}$

Dipandang dari aspek represif, Philipus Hadjon menyatakan bahwa sesungguhnya hukum administrasi sangat dominan karena tindak pidana korupsi hanya mungkin terjadi dalam konteks kerugian keuangan negara yang diakibatkan oleh maladministrasi dalam penggunaan wewenang, bentuk maladministrasi yang paling utama adalah penyalahgunaan wewenang. ${ }^{5}$

Maladministrasi menurut Pasal 1 angka 3 Undang-Undang Nomor 37 Tahun 2008 tentang Ombudsman Republik Indonesia adalah perilaku atau perbuatan melawan hukum, melampaui wewenang, menggunakan wewenang untuk tujuan lain dari yang menjadi tujuan wewenang tersebut, termasuk kelalaian atau pengabaian kewajiban hukum dalam penyelenggaraan pelayanan publik yang dilakukan oleh Penyelenggara Negara dan pemerintahan yang menimbulkan kerugian materiil dan/atau immateriil bagi masyarakat dan orang perseorangan.

Dalam penyelenggaraan pemerintahan dimungkinkan terjadinya penyalahgunaan wewenang karena adanya kesalahan administratif yang dilakukan oleh badan atau pejabat pemerintahan, walaupun Undang-Undang Nomor 30 Tahun 2014 
melarangnya. Larangan penyalahgunaan wewenang tersebut diatur dalam Pasal 17, yang meliputi:

a. Larangan melampaui wewenang;

b. Larangan mencampuradukkan wewenang; dan

c. Larangan bertindak sewenang-wenang.

Berkaitan dengan hal tersebut di atas maka permasalahannya adalah sebagai berikut: "Bagaimanakah akibat hukum penyalahgunaan wewenang administrasi pejabat pemerintahan yang menimbulkan kerugian keuangan negara? “

\section{B. Hasil dan Pembahasan}

Akibat Hukum Penyalahgunaan Wewenang Administrasi Pejabat Pemerintahan yang Menimbulkan Kerugian Keuangan Negara

Menurut Philipus M Hadjon, dalam hukum administrasi dikenal istilah kewenangan atau wewenang, yang seringkali disejajarkan dengan istilah “bevoegdheid”. Ada sedikit perbedaan antara istilah wewenang atau kewenangan dengan istilah bevoegdheid. Perbedaan terletak dalam karakter hukumnya. Istilah Belanda bevoegdheid digunakan baik dalam konsep hukum publik maupun hukum privat, sedangkan di Indonesia selalu digunakan dalam konsep hukum publik.

Sebagai suatu konsep hukum publik, wewenang terdiri atas sekurang-kurangnya tiga komponen, yaitu:
a. Pengaruh
b. Dasar hukum
c. Konformitas hukum.

Komponen pengaruh ialah bahwa penggunaan wewenang dimaksudkan untuk mengendalikan perilaku subyek hukum. Komponen dasar hukum, bahwa wewenang itu harus dapat ditunjuk dasar hukumnya, dan komponen konformitas hukum, mengandung makna adanya standar wewenang yaitu standar umum (semua jenis wewenang) dan standar khusus (untuk jenis wewenang tertentu). ${ }^{6}$

Bagir Manan sebagaimana dikutip oleh Ridwan HR berpendapat bahwa wewenang dalam bahasa hukum tidak sama dengan kekuasaan (macht). Kekuasaan

\footnotetext{
6 Philipus M. Hadjon dkk, Op Cit, (Yogyakarta: Gadjah Mada University Press, 2011), Halaman 10 - 11.
} 
hanya menggambarkan hak untuk berbuat atau tidak berbuat. Dalam hukum wewenang sekaligus berarti hak dan kewajiban (rechten en plichten). ${ }^{7}$

Menurut Philipus M. Hadjon, tanggung jawab pejabat dalam melaksanakan fungsinya dibedakan antara tanggung jawab jabatan dan tanggung jawab pribadi. Tanggung jawab jabatan berkenaan dengan legalitas (keabsahan) tindak pemerintahan. Dalam hukum administrasi, persoalan legalitas tindak pemerintahan berkaitan dengan pendekatan terhadap kekuasaan pemerintahan. Tanggung jawab pribadi berkaitan dengan pendekatan fungsionaris atau pendekatan perilaku dalam hukum administrasi. Tanggung jawab pribadi berkenaan dengan maladministrasi dalam penggunaan wewenang maupun public service. Pembedaan antara tanggung jawab jabatan dan tanggung jawab pribadi atas tindak pemerintahan membawa konsekuensi yang berkaitan dengan tanggung jawab pidana, tanggung gugat perdata dan tanggung gugat tata usaha negara (TUN). Tanggung jawab pidana adalah tanggung jawab pribadi. Dalam kaitan dengan tindak pemerintahan, tanggung jawab pribadi seorang pejabat berhubung dengan adanya maladministrasi. Tanggung gugat perdata dapat menjadi tanggung gugat jabatan berkaitan dengan perbuatan melanggar hukum oleh penguasa. Tanggung gugat perdata menjadi tanggung gugat pribadi apabila terdapat unsur maladministrasi. Tanggung gugat TUN pada dasarnya adalah tanggung gugat jabatan ${ }^{8}$.

Menurut Tatiek Sri Djatmiati, dalam konteks tindak pidana korupsi abuse of power (penyalahgunaan wewenang) atau unreasonableness (sewenang-wenang), keduanya merupakan parameter yang utama ada tidaknya penyimpangan dalam penggunaan wewenang pemerintahan tentunya di samping asas-asas hukum administrasi yang lain. Dalam hal terdapat unsur penyalahgunaan wewenang dan sewenang-wenang, maka terdapat unsur maladministrasi dan tentu ada unsur perbuatan melawan hukum, dan perbuatan itu menjadi tanggung jawab pribadi pejabat yang melakukannya. Abuse of power lebih luas pengertiannya daripada unreasonableness, namun dalam kajian hukum administrasi keduanya sangat diperlukan untuk menentukan ada tidaknya korupsi pejabat ${ }^{9}$.

Mencermati delik pidana penyalahgunaan kewenangan, kesempatan atau sarana yang ada karena jabatan yang dapat merugikan keuangan negara, Hernold

Ridwan HR, Hukum Administrasi Negara, (Jakarta: PT Raja GrafindoPersada, 2013), halaman 99 Philipus M. Hadjon dkk, Op. Cit., halaman 16-17.

Ibid, halaman 49. 
Ferry Makawimbang menyatakan bahwa kata kunci yang harus dijawab adalah "apa kewenangan itu, dan bagaimana kesempatan atau sarana yang ada karena jabatan itu”, sehingga dapat disalahgunakan dan dapat merugikan keuangan negara. Jika dilihat dari kata-kata tersebut mempunyai pengertian "kewenangan yang diperoleh karena jabatan" dan jabatan tersebut mempunyai akses terhadap keuangan negara. Karena banyak jabatan dan kewenangan walaupun disalahgunakan tidak berdampak pada perbuatan merugikan keuangan negara, berarti bahwa jabatan tersebut mempunyai kekuasaan atau kewenangan langsung atau tidak langsung yang dapat mempengaruhi keputusan yang mengakibatkan timbulnya hak dan kewajiban keuangan negara. ${ }^{10}$

Menurut Indriyanto Seno Adji, dalam kerangka hukum administrasi negara, parameter yang membatasi gerak bebas kewenangan aparatur negara (discretionary power) adalah detournement de povoir (penyalahgunaan wewenang) dan abus de droit (sewenang-wenang). Sedangkan dalam area hukum pidanapun memiliki kriteria yang membatasi gerak bebas kewenangan aparatur negara berupa unsur "wederechtelijkheid" dan menyalahgunakan kewenangan. ${ }^{11}$

Dalam Pasal 1 angka 5 Undang-Undang Nomor 30 Tahun 2014 tentang Administrasi Pemerintahan dinyatakan bahwa wewenang adalah hak yang dimiliki oleh Badan dan/atau Pejabat Pemerintahan atau penyelenggara negara lainnya untuk mengambil keputusan dan/atau tindakan dalam penyelenggaraan pemerintahan. Selanjutnya Pasal 1 angka 6 menyatakan bahwa, kewenangan pemerintahan yang selanjutnya disebut kewenangan adalah kekuasaan Badan dan/atau Pejabat Pemerintahan atau penyelenggara negara lainnya untuk bertindak dalam ranah hukum publik.

Pasal 8 Undang-Undang Nomor 30 Tahun 2014 tentang Administrasi Pemerintahan menyatakan bahwa:

1) Setiap Keputusan dan/atau Tindakan harus ditetapkan dan/atau dilakukan oleh Badan dan/atau Pejabat Pemerintahan yang berwenang.

2) Badan dan/atau Pejabat Pemerintahan dalam menggunakan Wewenang wajib berdasarkan:

a. peraturan perundang-undangan; dan

b. AUPB.

Hernold Ferry Makawimbang, Kerugian Keuangan Negara, (Yogyakarta: Thafa Media, 2014), halaman 38. Budi Suhariyanto, Persinggungan Kewenangan Mengadili Penyalahgunaan Diskresi antara Pengadilan TUN dan Pengadilan Tipikor, Jurnal Hukum dan Peradilan, Volume 7 Nomor 2, Juli 2018: 217 
3) Pejabat Administrasi Pemerintahan dilarang menyalahgunakan Kewenangan dalam menetapkan dan/atau melakukan Keputusan dan/atau Tindakan.

Indriyanto Seno Adji memberikan perspektif tentang penyalahgunaan kewenangan dalam 3 bentuk:

a. Penyalahgunaan kewenangan untuk melakukan tindakan-tindakan yang bertentangan dengan kepentingan umum atau untuk menguntungkan pribadi, kelompok atau golongan;

b. Penyalahgunaan kewenangan dalam arti bahwa tindakan pejabat tersebut adalah benar ditujukan untuk kepentingan umum, tetapi menyimpang dari tujuan diberikannya kewenangan tersebut oleh undang-undang atau peraturanperaturan lain;

c. Penyalahgunaan kewenangan dalam arti menyalahgunakan prosedur yang seharusnya dipergunakan untuk mencapai tujuan tertentu, tetapi telah menggunakan prosedur lain agar terlaksana.

Tiga bentuk pengertian tersebut secara maknawi menjadi domain kajian hukum administrasi. $^{12}$

Pasal 17 Undang-Undang Nomor 30 Tahun 2014 tentang Administrasi Pemerintahan mengatur tentang larangan penyalahgunaan wewenang yang dilakukan oleh Badan dan/atau Pejabat Pemerintahan yang meliputi larangan melampaui wewenang, larangan mencampuradukkan wewenang, dan/atau larangan bertindak sewenang-wenang.

Pasal 18 Undang-Undang Nomor 30 Tahun 2014 selanjutnya mengatur lebih lanjut tentang larangan penyalahgunaan wewenang, sebagai berikut :

1) Badan dan/atau Pejabat Pemerintahan dikategorikan melampaui Wewenang sebagaimana dimaksud dalam Pasal 17 ayat (2) huruf a apabila Keputusan dan/atau Tindakan yang dilakukan:

a. melampaui masa jabatan atau batas waktu berlakunya Wewenang;

b. melampaui batas wilayah berlakunya Wewenang; dan/atau

c. bertentangan dengan ketentuan peraturan perundang-undangan.

12 Nicken Sarwo Rini, Penyalahgunaan Kewenangan Administrasi dalam Undang-Undang Tindak Pidana Korupsi, Jurnal Penelitian Hukum DE JURE, ISSN 1410-5632 vol.18 No. 2, Juni 2018, 265 
2) Badan dan/atau Pejabat Pemerintahan dikategorikan mencampuradukkan Wewenang sebagaimana dimaksud dalam Pasal 17 ayat (2) huruf b apabila Keputusan dan/atau Tindakan yang dilakukan:

a. di luar cakupan bidang atau materi Wewenang yang diberikan; dan/atau

b. bertentangan dengan tujuan Wewenang yang diberikan.

3) Badan dan/atau Pejabat Pemerintahan dikategorikan bertindak sewenangwenang sebagaimana dimaksud dalam Pasal 17 ayat (2) huruf c apabila Keputusan dan/atau Tindakan yang dilakukan:

a. tanpa dasar Kewenangan; dan/atau

b. bertentangan dengan Putusan Pengadilan yang berkekuatan hukum tetap.

Pasal 19 Undang-Undang Nomor 30 Tahun 2014 mengatur lebih lanjut tentang akibat hukum dari suatu Keputusan dan/atau Tindakan yang memenuhi kriteria penyalahgunaan wewenang, sebagai berikut:

1) Keputusan dan/atau Tindakan yang ditetapkan dan/atau dilakukan dengan melampaui Wewenang sebagaimana dimaksud dalam Pasal 17 ayat (2) huruf a dan Pasal 18 ayat (1) serta Keputusan dan/atau Tindakan yang ditetapkan dan/atau dilakukan secara sewenang-wenang sebagaimana dimaksud dalam Pasal 17 ayat (2) huruf c dan Pasal 18 ayat (3) tidak sah apabila telah diuji dan ada Putusan Pengadilan yang berkekuatan hukum tetap.

2) Keputusan dan/atau Tindakan yang ditetapkan dan/atau dilakukan dengan mencampuradukkan Wewenang sebagaimana dimaksud dalam Pasal 17 ayat (2) huruf b dan Pasal 18 ayat (2) dapat dibatalkan apabila telah diuji dan ada Putusan Pengadilan yang berkekuatan hukum tetap.

Pengadilan yang berwenang melakukan penilaian ada tidaknya unsur penyalahgunaan wewenang yang dilakukan oleh Badan dan/atau Pejabat Pemerintahan adalah Peradilan Tata Usaha Negara, sebagaimana diatur dalam Pasal 21 dan Pasal 87 Undang -Undang Nomor 30 Tahun 2014.

Pasal 21 menyatakan bahwa:

1) Pengadilan berwenang menerima, memeriksa, dan memutuskan ada atau tidak ada unsur penyalahgunaan Wewenang yang dilakukan oleh Pejabat Pemerintahan. 
2) Badan dan/atau Pejabat Pemerintahan dapat mengajukan permohonan kepada Pengadilan untuk menilai ada atau tidak ada unsur penyalahgunaan Wewenang dalam Keputusan dan/atau Tindakan.

3) Pengadilan wajib memutus permohonan sebagaimana dimaksud pada ayat (2) paling lama 21 (dua puluh satu) hari kerja sejak permohonan diajukan.

4) Terhadap putusan Pengadilan sebagaimana dimaksud pada ayat (3) dapat diajukan banding ke Pengadilan Tinggi Tata Usaha Negara.

5) Pengadilan Tinggi Tata Usaha Negara wajib memutus permohonan banding sebagaimana dimaksud pada ayat (4) paling lama 21 (dua puluh satu) hari kerja sejak permohonan banding diajukan.

6) Putusan Pengadilan Tinggi Tata Usaha Negara sebagaimana dimaksud pada ayat (5) bersifat final dan mengikat.

Menindaklanjuti ketentuan tersebut di atas, maka Mahkamah Agung Republik Indonesia mengeluarkan Peraturan Mahkamah Agung Nomor 4 Tahun 2015 tentang Pedoman Beracara Penilaian unsur Penyalahgunaan Wewenang. Dalam Pasal 2 ayat (1) dan ayat (2) serta Pasal 3 Peraturan Mahkamah Agung Nomor 4 Tahun 2015 tersebut diatur hal tentang kekuasaan pengadilan dan kedudukan hukum (legal standing) Pemohon, sebagaimana hal berikut di bawah ini:

Pasal 2

1) Pengadilan berwenang menerima, memeriksa dan memutus permohonan penilaian ada atau tidak ada penyalahgunaan wewenang dalam keputusan dan/atau tindakan pejabat pemerintah sebelum adanya proses pidana.

2) Pengadilan baru berwenang menerima, memeriksa dan memutus penilaian permohonan sebagaimana dimaksud ayat (1) setelah adanya hasil pengawasan aparat pengawasan intern pemerintah.

Kewenangan PTUN untuk mengadili permohonan penilaian ada tidaknya penyalahgunaan wewenang pejabat pemerintah dapat dilakukan sebelum adanya proses pidana. Hal tersebut memberikan kesan bahwa proses peradilan pidana dapat mengesampingkan proses peradilan administrasi.

Di sisi lain PTUN baru berwenang mengadili permohonan penilaian ada tidaknya penyalahgunaan wewenang pejabat pemerintah setelah adanya hasil pengawasan aparat pengawasan intern pemerintah (APIP), sehingga Pemohon tidak 
serta merta dapat mengajukan permohonan penilaian kepada PTUN. Oleh karena itu maka berdasarkan Pasal 3 dinyatakan bahwa:

"Badan dan/atau Pejabat Pemerintahan yang merasa kepentingannya dirugikan oleh hasil pengawasan oleh aparat pengawasan intern pemerintah dapat mengajukan permohonan kepada pengadilan yang berwenang berisi tuntutan agar keputusan dan/atau tindakan Pejabat Pemerintah dinyatakan ada atau tidak ada unsur penyalahgunaan wewenang."

Dalam materi permohonan sebagaimana diatur dalam Pasal 4 ayat (1) huruf d angka 2, maka hal-hal yang dimohonkan oleh Pejabat Pemerintahan untuk diputus oleh hakim adalah:

a. Mengabulkan permohonan Pemohon seluruhnya;

b. Menyatakan Keputusan dan/atau Tindakan Pejabat Pemerintahan tidak ada unsur penyalahgunaan wewenang;

c. Memerintahkan kepada Negara untuk mengembalikan kepada Pemohon uang yang telah dibayar, dalam hal Pemohon telah mengembalikan kerugian negara sebagaimana dimaksud dalam Pasal 20 ayat (4) dan ayat (6) Undang-Undang Nomor 30 Tahun 2014.

Berdasarkan ketentuan tersebut di atas, maka diketahui bahwa PTUN memperoleh kewenangan atribusi tidak hanya terbatas pada pengawasan dan pengujian terhadap penyelenggaraan pemerintahan saja, melainkan juga dalam hal memutuskan ada tidaknya unsur penyalahgunaan wewenang yang dilakukan oleh pejabat pemerintahan.

Selanjutnya Pasal 20 Undang-Undang Nomor 30 Tahun 2014 mengatur halhal sebagai berikut:

1) Pengawasan terhadap larangan penyalahgunaan Wewenang sebagaimana dimaksud dalam Pasal 17 dan Pasal 18 dilakukan oleh aparat pengawasan intern pemerintah.

2) Hasil pengawasan aparat pengawasan intern pemerintah sebagaimana dimaksud pada ayat (1) berupa

a. tidak terdapat kesalahan;

b. terdapat kesalahan administratif; atau

c. terdapat kesalahan administratif yang menimbulkan kerugian keuangan negara. 
3) Jika hasil pengawasan aparat intern pemerintah berupa terdapat kesalahan administratif sebagaimana dimaksud pada ayat (2) huruf b, dilakukan tindak lanjut dalam bentuk penyempurnaan administrasi sesuai dengan ketentuan peraturan perundang-undangan.

4) Jika hasil pengawasan aparat intern pemerintah berupa terdapat kesalahan administratif yang menimbulkan kerugian keuangan negara sebagaimana dimaksud pada ayat (2) huruf c, dilakukan pengembalian kerugian keuangan negara paling lama 10 (sepuluh) hari kerja terhitung sejak diputuskan dan diterbitkannya hasil pengawasan.

5) Pengembalian kerugian negara sebagaimana dimaksud pada ayat (4) dibebankan kepada Badan Pemerintahan, apabila kesalahan administratif sebagaimana dimaksud pada ayat (2) huruf c terjadi bukan karena adanya unsur penyalahgunaan Wewenang.

6) Pengembalian kerugian negara sebagaimana dimaksud pada ayat (4) dibebankan kepada Pejabat Pemerintahan, apabila kesalahan administratif sebagaimana dimaksud pada ayat (2) huruf c terjadi karena adanya unsur penyalahgunaan Wewenang.

Pengawasan terhadap larangan penyalahgunaan wewenang yang dilakukan Pejabat Pemerintahan tersebut dilakukan oleh aparat pengawasan intern pemerintah (APIP), yang diatur dalam Pasal 48 ayat (2) Peraturan Pemerintah Nomor 60 Tahun 2008 tentang Sistem Pengendalian Intern Pemerintah (SPIP), dimana disebutkan bahwa APIP melakukan pengawasan intern melalui: a. audit, b. reviu, c. evaluasi, d. pemantauan, dan e. kegiatan pengawasan lainnya. Selanjutnya Pasal 49 ayat (1) dinyatakan bahwa aparat pengawasan intern pemerintah sebagaimana dimaksud dalam Pasal 48 ayat (1) terdiri atas: a. BPK; b. Inspektorat Jenderal atau nama lain yang secara fungsional melaksanakan pengawasan intern; c. Inspektorat Provinsi; dan d. Inspektorat Kabupaten/Kota.

Peraturan Pemerintah Nomor 12 Tahun 2017 tentang Pembinaan dan Pengawasan Penyelenggaraan Pemerintahan Daerah menyatakan bahwa APIP adalah inspektorat jenderal kementerian, unit pengawasan lembaga pemerintah nonkementerian, inspektorat provinsi, dan inspektorat Kabupaten/kota. Selanjutnya ditegaskan bahwa pengawasan penyelenggaraan pemerintahan daerah yang dilaksanakan oleh APIP dilaksanakan berdasarkan prinsip: a. profesional; b. 
independen; c. objektif; d. tidak tumpang tindih antar-APIP; dan e. berorientasi pada perbaikan dan peringatan dini. Oleh karena itu maka tindak lanjut hasil pembinaan dan pengawasan berdasarkan Pasal 25 ayat (7), perlu dilakukan koordinasi antara APIP dan aparat penegak hukum yang dilaksanakan sesuai dengan fungsi dan kewenangan masing-masing antara: a. Inspektorat Jenderal Kementerian, Inspektorat Jenderal Kementerian terkait, unit pengawasan lembaga pemerintah nonkementerian, inspektorat provinsi, dan/atau inspektorat kabupaten/kota; dan b. kepolisian dan/atau kejaksaan.

Selanjutnya Pasal 25 ayat (9) menyatakan bahwa: Jika berdasarkan hasil koordinasi sebagaimana dimaksud pada ayat (7) ditemukan bukti adanya penyimpangan yang bersifat administratif, proses lebih lanjut diserahkan kepada APIP untuk ditindaklanjuti sesuai dengan ketentuan dalam Peraturan Pemerintah ini dan ketentuan peraturan perundang-undangan yang mengatur mengenai administrasi pemerintahan. Sedangkan ketentuan ayat (10) menyatakan bahwa jika berdasarkan hasil koordinasi sebagaimana dimaksud pada ayat (7) ditemukan bukti permulaan adanya penyimpangan yang bersifat pidana, proses lebih lanjut diserahkan kepada aparat penegak hukum untuk ditindaklanjuti sesuai dengan ketentuan peraturan perundang-undangan.

Berkaitan dengan terminologi keuangan negara sebagaimana dirumuskan dalam Undang-Undang Nomor 17 Tahun 2003 tentang Keuangan Negara, khususnya Pasal 2 huruf g dan i pernah diajukan constitutional review ke Mahkamah Konstitusi Republik Indonesia, karena dianggap bertentangan dengan Pasal 23 ayat (1), Pasal 28 C ayat (2), Pasal 28 D ayat (1), dan Pasal 31 ayat (4) UUD NRI Tahun 1945. Terhadap perkara yang diajukan tersebut, maka Mahkamah Konstitusi mengeluarkan Putusan Nomor 48/PUU-XI/2013. Selain hal tersebut, maka Pasal 2 huruf g dan i Undang-undang Nomor 17 Tahun 2003 tentang Keuangan Negara juga pernah diajukan constitutional review ke Mahkamah Konstitusi karena dianggap bertentangan dengan Pasal 23 ayat (1), Pasal 23 E ayat (1), dan Pasal 28 D ayat (1) UUD NRI Tahun 1945. Hal tersebut juga sudah diputuskan oleh Mahkamah Konstitusi melalui Putusan Mahkamah Konstitusi Nomor 62/PUU-XI/2013. Kedua putusan Mahkamah Konstitusi tersebut menolak seluruhnya permohonan Pemohon terhadap permohonan constitutional review yang dimohonkan oleh Pemohon. 
Terminologi keuangan negara menurut Undang-Undang Nomor 31 Tahun 1999 juncto Undang-undang Nomor 20 Tahun 2001 tentang Pemberantasan Tindak Pidana Korupsi, diatur dalam Penjelasan Umum Undang-undang Nomor 31 Tahun 1999 yang menyatakan bahwa keuangan negara yang dimaksud adalah seluruh kekayaan negara dalam bentuk apapun, yang dipisahkan atau yang tidak dipisahkan, termasuk di dalamnya segala bagian kekayaan negara dan segala hak dan kewajiban yang timbul karena:

a) Berada dalam penguasaan, pengurusan, dan pertanggungjawaban pejabat lembaga negara, baik di tingkat pusat maupun di daerah;

b) Berada dalam penguasaan, pengurusan, dan pertanggungjawaban Badan Usaha Milik Negara/Badan Usaha Milik Daerah, yayasan, badan hukum, dan perusahaan yang menyertakan modal negara, atau perusahaan yang menyertakan modal pihak ketiga berdasarkan perjanjian dengan negara.

Menurut Hernold Ferry Makawimbang, hakikat pengertian keuangan negara secara substansial antara kedua undang-undang tersebut tidak berbeda, hanya pendekatan pengaturan yang berbeda, Undang-Undang Nomor 17 Tahun 2003 pendekatan pada pengaturan keuangan negara dari aspek "objek, lingkup dan luas", sedangkan Penjelasan alinea ke 3 Undang-Undang Nomor 31 Tahun 1999, mengatur keuangan negara dari aspek "wilayah penguasaan pengelolaan keuangan negara", tetapi jika dilihat secara substansial "content" keduanya sama, hanya pendekatan melihat pengelolaannya yang berbeda. ${ }^{13}$

Terminologi "kerugian negara" yang digunakan adalah berdasarkan rumusan Undang-Undang Nomor 1 Tahun 2004 tentang Perbendaharaan Negara Pasal 1 angka 22 yang menyatakan bahwa: "kerugian negara/daerah adalah kekurangan uang, surat berharga, dan barang, yang nyata dan pasti jumlahnya sebagai akibat perbuatan melawan hukum baik sengaja maupun lalai." Dalam Penjelasan Umum angka 6 tentang Penyelesaian Kerugian Negara, ditegaskan bahwa setiap kerugian negara/daerah yang disebabkan oleh tindakan melanggar hukum atau kelalaian seseorang harus diganti oleh pihak yang bersalah. Dengan penyelesaian kerugian tersebut negara/daerah dapat dipulihkan dari kerugian yang telah terjadi. Sehubungan dengan itu, setiap pimpinan kementerian/lembaga/kepala satuan kerja perangkat daerah wajib segera melakukan tuntutan ganti rugi setelah mengetahui bahwa

13 Hernold Ferry Makawimbang, Op cit, halaman 11 
kementerian negara/lembaga/satuan kerja perangkat daerah yang bersangkutan terjadi kerugian. Pengenaan ganti kerugian negara/daerah terhadap bendahara ditetapkan oleh Badan Pemeriksa Keuangan, sedangkan pengenaan ganti kerugian negara/daerah terhadap pegawai negeri bukan bendahara ditetapkan oleh menteri/pimpinan lembaga/gubernur/bupati/ walikota. Bendahara/pegawai negeri bukan bendahara, dan pejabat lain yang telah ditetapkan untuk mengganti kerugian negara/daerah dapat dikenai sanksi administratif dan/atau sanksi pidana apabila terbukti melakukan pelanggaran administratif dan/atau pidana.

Menurut Hernold Ferry Makawimbang ${ }^{14}$, dalam praktek (in concreto) di pengadilan tindak pidana korupsi, penggunaan terminologi"kerugian negara" diintepretasikan atau dianalogikan sama dengan "kerugian keuangan negara" sebagaimana dimaksud dalam Pasal 2 dan Pasal 3 Undang-Undang Nomor 31 Tahun 1999. Padahal wilayah pengaturan "kerugian negara" yang termuat dalam Pasal 1 angka 22 Undang-Undang Nomor 1 Tahun 2004 adalah ranah hukum administrasi, berbeda dengan pengaturan "kerugian keuangan negara” sebagai ranah hukum pidana

Berkaitan dengan penyalahgunaan wewenang yang dilakukan oleh pejabat pemerintahan, beberapa pakar hukum administrasi negara (yang diminta memberikan keterangan ahli di persidangan) menyatakan bahwa keputusan pejabat negara baik dalam rangka beleid (vrijsbestuur) maupun diskresi (kebijaksanaan atau dicretionary power) tidak dapat dilarikan ke area hukum pidana, meskipun dalam kebijakan terjadi penyimpangan administratif, maka penilaian terhadap penyimpangan itu adalah masuk ranah hukum administrasi negara, yang tidak dapat dijadikan penilaian hukum pidana, khususnya dalam konteks tindak pidana korupsi. Di kalangan penegak hukum sendiri terdapat persepsi yang berbeda dalam memberikan batasan kapan kebijakan atau diskresi masuk dalam ranah pidana atau sekedar pelanggaran administratif, khususnya dalam kaitan dengan kebijakan atau tindakan yang salah dari pejabat yang mengakibatkan kerugian negara. ${ }^{15}$

Dalam ranah Hukum Administrasi Negara melalui berbagai peraturan perundangan juga terdapat ketidakseragaman terminologi kerugian keuangan negara. Hal tersebut dapat dilihat juga pada ketentuan Undang-Undang Nomor 30 Tahun 2014 tentang Administrasi Pemerintahan yang mengatur tentang "kesalahan 
administratif yang menimbulkan kerugian keuangan negara", di sisi lain juga terdapat rumusan "kerugian negara". Pada ketentuan yang lain sebagaimana telah diuraikan di atas mengatur pula tentang "kerugian negara".

\section{Simpulan}

Berdasarkan hal-hal tersebut di atas, maka dapat disimpulkan bahwa dalam melaksanakan fungsi pemerintahan, maka pejabat pemerintahan dilarang menyalahgunakan wewenang. Pengawasan terhadap larangan penyalahgunaan wewenang tersebut dilakukan oleh APIP. Hasil pengawasan APIP berupa: tidak terdapat kesalahan, terdapat kesalahan administratif, atau terdapat kesalahan administratif yang menimbulkan kerugian keuangan negara. Berdasarkan hasil pengawasan APIP tersebut, pejabat pemerintahan yang dianggap telah melakukan penyalahgunaan wewenang, dapat mengajukan permohonan penilaian unsur ada tidaknya penyalahgunaan wewenang dalam mengeluarkan keputusan dan/atau tindakan kepada Peradilan Tata Usaha Negara berdasarkan Peraturan Mahkamah Agung Nomor 4 Tahun 2015, sebelum adanya proses pidana.

Akibat hukum pejabat pemerintahan terhadap penyalahgunaan wewenang

yang menimbulkan kerugian keuangan negara karena adanya kesalahan administratif/maladministratif menjadi tanggung jawab pribadi dengan mengembalikan kerugian keuangan negara yang ditimbulkan sebagai akibat dari perbuatan yang dia lakukan.

\section{Daftar Pustaka}

Fuady, Munir. 2009. Teori Negara Hukum Modern (Rechtstaat). Bandung: Refika Aditama.

HR, Ridwan. 2013. Hukum Administrasi Negara. Jakarta: PT Raja Grafindo Persada Makawimbang, Hernold Ferry. 2014. Kerugian Keuangan Negara. Yogyakarta: Thafa Media.

Marbun, SF dan MD, Moh. Mahfud. 1987. Pokok-pokok Hukum Administrasi Negara. Yogyakarta: Liberty.

Philipus M. Hadjon dkk. 2011. Hukum Administrasi dan Tindak Pidana Korupsi. Yogyakarta: Gadjah Mada University Press.

Rini, Nicken Sarwo. 2018. Penyalahgunaan Kewenangan Administrasi dalam Undang-Undang Tindak Pidana Korupsi. Jurnal Penelitian Hukum DE JURE, ISSN 1410-5632 vol.18 No. 2, Juni 2018, 265

Suhariyanto, Budi. 2018. Persinggungan Kewenangan Mengadili Penyalahgunaan Diskresi antara Pengadilan TUN dan Pengadilan Tipikor. Jurnal Hukum dan Peradilan, Volume 7 Nomor 2, Juli 2018: 217

Thamrin, Muhammad Aksan. Kapan Kebijakan Dapat Dipidana. 2017. https://www.kejati-sulsel.go.id diakses 20 Agustus 2017 
Tjandra, W Riawan. 2009. Hukum Administrasi Negara. Yogyakarta: Penerbit Universitas Atma Jaya. 